ISSN 1392-3196 / e-ISSN 2335-8947

Zemdirbyste-Agriculture, vol. 101, No. 3 (2014), p. 271-278

DOI 10.13080/z-a.2014.101.035

\title{
Assessment of energy biomass potential and greenhouse gas emissions from biogas production from perennial grasses
}

\author{
Arvydas NEKROŠIUS ${ }^{1}$, Kęstutis NAVICKAS ${ }^{1}$, Kęstutis VENSLAUSKAS ${ }^{1}$, \\ Žydrè KADŽIULIENE ${ }^{2}$, Vita TILVIKIENE² ${ }^{2}$ \\ ${ }^{1}$ Aleksandras Stulginskis University \\ Studentu 11, Akademija, Kaunas distr., Lithuania \\ E-mail: arvydas.nekrosius@asu.lt \\ ${ }^{2}$ Institute of Agriculture, Lithuanian Research Centre for Agriculture and Forestry \\ Instituto 1, Akademija, Kèdainiai distr., Lithuania
}

\begin{abstract}
The research was aimed to investigate the energy biomass productivity and biogas production from silage of different perennial grasses with evaluation of greenhouse gas emissions through the entire process from biomass cultivation to processing. The experiments with perennial grasses - cocksfoot (Dactylis glomerata L.), tall fescue (Festuca arundinacea Scherb.) and reed canary grass (Phalaris arundinacea L.) were carried out at Institute of Agriculture, Lithuanian Research Centre for Agriculture and Forestry in 2008-2010. The swards were grown in an Endocalcari-Endohypogleyic Cambisol (CMg- $n$-w-can), which contained: organic carbon - $1.61-1.75 \%$, available $\mathrm{P}-145-224 \mathrm{mg} \mathrm{kg}^{-1}$ and $\mathrm{K}-128-158 \mathrm{mg} \mathrm{kg}^{-1}$, soil $\mathrm{pH}$ ranging between 6.7-7.0. The three perennial grass species with varying yields of biomass were used to ensure a steady operation of the selected biogas plant of $500 \mathrm{~kW}_{\mathrm{e}}$ electric power. The different quantities of biomass feedstock and varying energy input are required for such biogas plant. Therefore all data correspond to a biogas cogeneration plant of $500 \mathrm{~kW}_{\mathrm{e}}$ electric power. Required land area for the same amount of energy produced depends on species of perennial grasses, rates of fertilization and number of cuts. These results mainly depended on the biomass productivity and biogas yield from dry mass. Biomass yield from dry matter in the first year of use of tall fescue cut twice per vegetation season was higher compared to that cut three times, while cocksfoot and reed canary grass yielded better cut three times compared to cut twice. The highest yield was obtained in tall fescue swards cut twice and fertilized with $\mathrm{N}_{180}$. The total balance of greenhouse gas emissions showed their mitigation and ranged from 0.206 to $0.298 \mathrm{~kg} \mathrm{CO}_{2}$ eq kWh${ }^{-1}$.
\end{abstract}

Key words: anaerobic digestion, energy crops, life cycle assessment.

\section{Introduction}

Over the past decades, along with the growing popularity of renewable energy sources in Europe there has been a rapidly growing interest in biogas production. Biogas is extracted by anaerobic digestion of different types of organic materials such as animal slurry and manure, sewage sludge, food and other organic wastes and energy crops (Jury et al., 2010). It is observed that mixtures of animal manure and energy crops positively influenced biogas plant operation and increased biogas yields. Energy obtained from biogas replaces fossil fuel extracted energy and thus reduces greenhouse gas emissions and mitigates the influence on climate change as well as significantly reduces odour. The remaining substrate after anaerobic digestion can be used to fertilize energy crops instead of mineral fertilizers requiring a lot of energy, along with a lot of emissions dispersing during manufacturing process.

European Parliament offers to promote biogas extraction without compromising food production. Therefore, one of the most potential and promising long-term alternatives for non-food raw materials used in the production of biogas is energy plant biomass (Grieder et al., 2012; Butkutè et al., 2014). In Germany, approximately 2000 biogas plants use biomass of energy crops. Roughly $15 \%$ of the German biogas plants use plant biomass as a sole feedstock. Others use mixtures of plant biomass, manure or other organic waste. More than $50 \%$ of the biogas plants use different mixtures containing $50-89 \%$ of plant biomass (Grieder et al., 2012). Maize silage biomass is most popular in the mixtures of manure and municipal wastewater, which is used by more than $90 \%$ of the biogas plants surveyed. Maize performs well in warm and wet weather conditions; the optimal temperature for growing is $18-24^{\circ} \mathrm{C}$. The cost of maize silage energy unit is about $20-30 \%$ lower compared to that of grass and almost twice as low as that of spring barley. In southern countries, biomass yield of maize is 20-30 $\mathrm{t} \mathrm{ha}^{-1}$ while in northern countries it is only 10 $20 \mathrm{tha}^{-1}$. The energy input for growth of the same amount of maize biomass in southern countries is significantly 
lower compared to northern (Seppälä et al., 2012). That is the reason why in northern countries alternative crops should be used for biogas production. The alternative to maize can be sourced to perennial grasses that are adapted to local climate conditions.

The suitability of grass biomass for biogas production is proven by scientific research and practical experience (Hartmann, 2006). The investigated biogas yield from different grass species using different harvest periods and methods shows that it varies in a very wide range (from 0.08 to $0.86 \mathrm{~m}^{3} \mathrm{~kg}^{-1}$ dry matter). In the northern part of middle latitudes, perennial grasses - cocksfoot (Dactylis glomerata), tall fescue (Festuca arundinacea) and reed canary grass (Phalaris arundinacea) are promising plants for biogas production (Tilvikienè et al., 2012). These perennial grasses are considered environmentally-friendly, since they can grow in poor soils and do not require intensive fertilization. The species are relatively resistant to drought, as they have a well-developed root system, have good overwintering abilities, have excellent weed suppression, good regrowth after cuts and may be grown in the same place for a long time. Grasses grown for biofuels are recommended to be cut twice per season. The same machinery can be used for sowing and harvesting as for the preparation of feed for livestock. Moreover, the same species can be used both for fodder and biogas.

The energy crop productivity is a limiting factor for energy potential per hectare. The yield is also dependent on the climate, soil and cultivation technologies, harvesting time during the season. Therefore a lot of discussions focus on cultivation of plants intended for bioenergy production. An indicator of energy conversion efficiency is also important (Navickas et al., 2008). Nutrients from biomass conversion can be returned to the soil for a sustainable renewable energy production system, which can displace greenhouse gas emissions from fossil energy consumption (Wilkie, 2008). Hence, there is a need for representative and up-to-date high quality data on the environmental performance of the biogas technologies. The biogas industry is aware of the importance of cleaner biogas production (Wilkie, 2008), utilization and environmental impacts mitigation strategies based on life cycle assessment (LCA) techniques (Poeschl et al., 2012 a; b). Generally, biogas production is considered as a cost-effective technology that can stem greenhouse gas (GHG) emission growth by recovering methane and using it as a renewable energy source (IPCC, 2006; Cornejo, Wilkie, 2010).

Many studies have been conducted concerning the LCA and environmental sustainability of biogas production systems (Poeschl et al., 2010; Bacenetti et al., 2013; Lijó et al., 2014) and biofuels. The study has to be carried out considering a cradle-to-grave perspective and thus, special attention has been paid to the feedstock production and biogas production process (Bacenetti et al., 2013) and fertilization of crops after anaerobic digestion systematically taking into account exploitation of natural resources (Klinglmair et al., 2014). For instance, the GHG emissions of electricity generation from biogas vary from 0.143 to $0.160 \mathrm{~kg} \mathrm{CO}_{2}$ eq $\mathrm{kWh}^{-1}$ (Dressler et al., 2012). In comparison to the fossil fuels reference system, the electricity production using biogas saves GHG emissions from 0.188 to $1.193 \mathrm{~kg} \mathrm{CO}$ eq $\mathrm{kWh}^{-1}$ (Bacenetti et al., 2013).

The objective of the study is to determine the energy potential of biogas production from different types of perennial grass silage and GHG emissions during the processes from biomass cultivation to processing.

\section{Materials and methods}

In order to evaluate the impact of soil tillage, biomass cultivation and processing, machinery and equipment on the environment, 12 biomass and biogas production scenarios were set up (Fig. 1). The scenarios were based on the grass species, number of cuts per growing season and nitrogen fertilizer rate. The balances of greenhouse gas (GHG) emissions from perennial grass biomass cultivation and processing into biogas was estimated per one grass-growing season - in the first year of sward use.

\begin{tabular}{|c|c|c|c|c|c|c|c|c|c|c|c|c|}
\hline Scenario & $\mathrm{SC} 1$ & $\mathrm{SC} 2$ & $\mathrm{SC} 3$ & $\mathrm{SC} 4$ & SC5 & SC6 & $\mathrm{SC} 7$ & $\mathrm{SC} 8$ & SC9 & $\mathrm{SC} 10$ & $\mathrm{SC} 11$ & $\mathrm{SC} 12$ \\
\hline Fertilization rate & $\mathrm{N}_{90}$ & $\mathrm{~N}_{180}$ & $\mathrm{~N}_{90}$ & $\mathrm{~N}_{180}$ & $\mathrm{~N}_{90}$ & $\mathrm{~N}_{180}$ & $\mathrm{~N}_{90}$ & $\mathrm{~N}_{180}$ & $\mathrm{~N}_{90}$ & $\mathrm{~N}_{180}$ & $\mathrm{~N}_{90}$ & $\mathrm{~N}_{180}$ \\
\hline Harvests per year & \multicolumn{2}{|c|}{3} & \multicolumn{2}{|c|}{2} & \multicolumn{2}{|c|}{3} & \multicolumn{2}{|c|}{2} & \multicolumn{2}{|c|}{3} & \multicolumn{2}{|c|}{2} \\
\hline Perennial grass species & \multicolumn{4}{|c|}{$\begin{array}{c}\text { Cocksfoot grass } \\
\text { (Dactylis glomerata) }\end{array}$} & \multicolumn{4}{|c|}{$\begin{array}{c}\text { Tall fescue grass } \\
\text { (Festuca arundinacea) }\end{array}$} & \multicolumn{4}{|c|}{$\begin{array}{l}\text { Reed canary grass } \\
\text { (Phalaris arundinacea })\end{array}$} \\
\hline
\end{tabular}

Figure 1. Scenarios of perennial grass cultivation and processing of biomass into biogas

The experiments with high yielding perennial grasses - cocksfoot (Dactylis glomerata L.), tall fescue (Festuca arundinacea Scherb.) and reed canary grass (Phalaris arundinacea L.) were carried out at Institute of Agriculture, Lithuanian Research Centre for Agriculture and Forestry in 2008-2010. The swards were grown in the soil, which contained: organic carbon $-1.61-1.75 \%$, available $\mathrm{P}-145-224 \mathrm{mg} \mathrm{kg}^{-1}$ and $\mathrm{K}-128$ $158 \mathrm{mg} \mathrm{kg}^{-1}$, soil $\mathrm{pH}$ ranging between $6.7-7.0$, EndocalcariEndohypogleyic Cambisol (CMg- $n$-w-can). Two levels of mineral nitrogen fertilizer $\mathrm{N}_{90}$ and $\mathrm{N}_{180}$ were applied for the swards cut twice $\left(1^{\text {st }}\right.$ cut at flowering stage, $2^{\text {nd }}$ cut in late autumn) and three ( $1^{\text {st }}$ cut at heading stage, $2^{\text {nd }}$ cut at the end of July and $3^{\text {rd }}$ cut in late autumn) times per season. The experiment was designed in randomised blocks with four replicates. The experiment was replicated twice: the first experiment was established in 2008, the second in 2009. The annual biomass yield of the first year of sward use was evaluated. The levels of significance were analysed using a three-factor analysis of variance using Dunkan's test at 0.05 significance level. 
The technological flow scheme (Navickas, Venslauskas, 2012) is designed for perennial grass cultivation, silage production and processing into biogas (Fig. 2). It covers soil cultivation, crop establishment, maintenance, fertilization, harvesting and preparation for ensiling, storage, anaerobic digestion and usage of primary and secondary by-products. The same methodology was applied by other authors (Jury et al., 2010; Poeschl et al., 2012 a; b; Lijó et al., 2014).

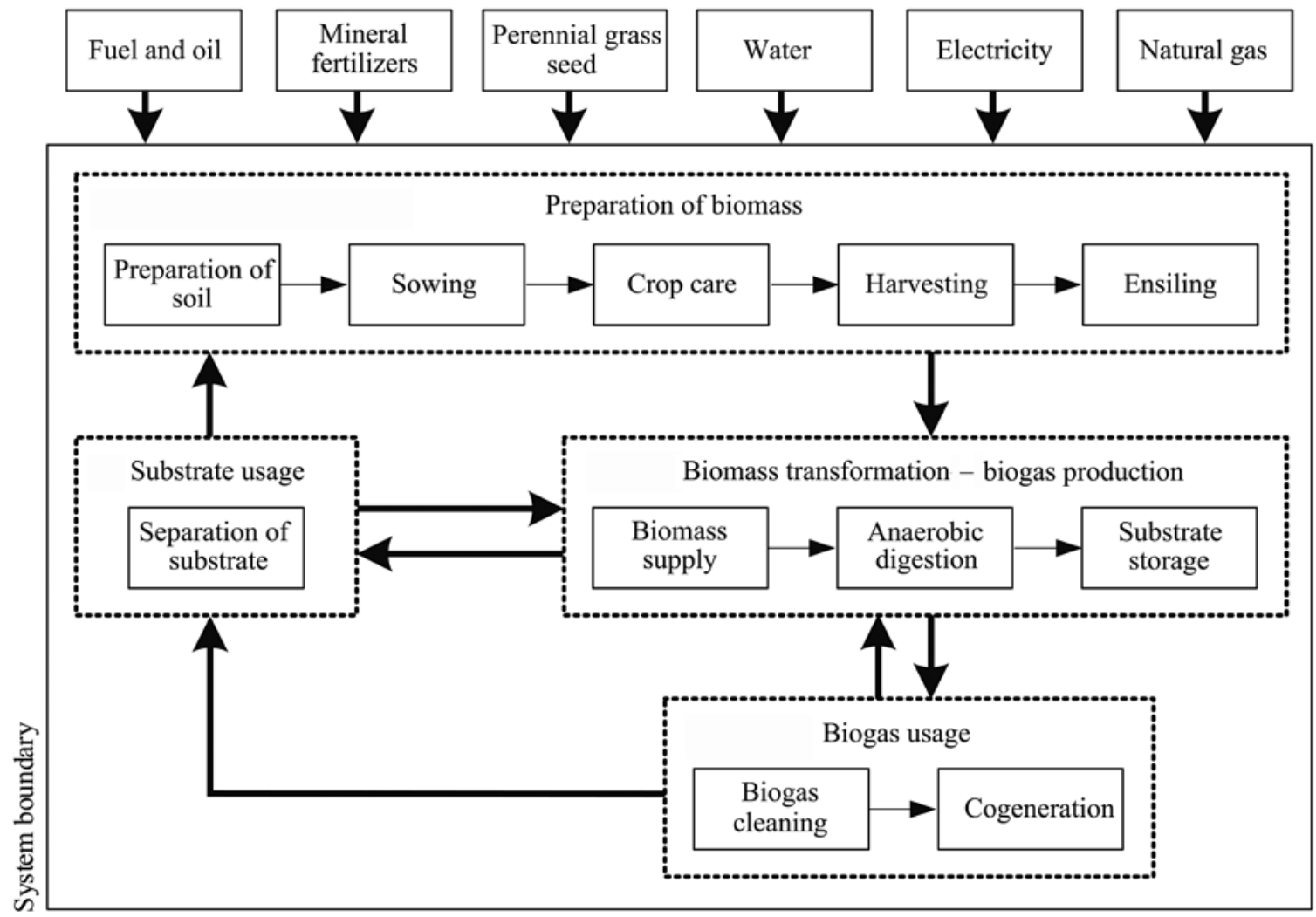

Figure 2. Flow scheme of technological operations of anaerobic digestion of perennial grass biomass

In each stage of perennial grass biomass cultivation and preparation, the appropriate equipment and agricultural machinery are used. Therefore this directly and indirectly influences environmental pollution. In this study pollution caused by equipment and agricultural machinery was assessed by potential of emissions. Information concerning the production of the different inputs (machinery, mineral fertilizers, seeds) as suggested by Bacenetti et al. (2013) was based on the secondary data taken from the database Ecoinvent (2014). Agricultural machinery arrival and departure from the field, fuelling (delivery to the field) and turn around at the headland is included in the calculation process. The average distance from the field to mineral fertilizer warehouse is assumed to be $3 \mathrm{~km}$, to farm machinery site $-3.1 \mathrm{~km}$, and to silage storage $-3 \mathrm{~km}$. Technical agricultural machinery parameters and average fuel consumption are given by the manufacturers and taken from the database Ecoinvent.

The field for perennial grasses was shallowploughed with a $3.5 \mathrm{~m}$ working width plough with seven bodies, dragged by an average of $8 \mathrm{~km} \mathrm{~h}^{-1}$ speed with a $155 \mathrm{hp}(114 \mathrm{~kW})$ tractor. Then the soil was loosened with 75 tines and $6 \mathrm{~m}$ working width cultivator, dragged by an average of $10 \mathrm{~km} \mathrm{~h}^{-1}$ speed with the tractor indicated above. Perennial grasses were sown at $18 \mathrm{~kg} \mathrm{ha}^{-1}$ rate using $4 \mathrm{~m}$ working width of 33 rows sowing machine, pulling by an average of $8 \mathrm{~km} \mathrm{~h}^{-1}$ speed. Additional application of mineral fertilizers were spread using a $24 \mathrm{~m}$ working width centrifugal fertilizer spreader. The field was fertilized at 90 and $180 \mathrm{~kg} \mathrm{ha}^{-1}$ of nitrogen rate.

Perennial grass biomass was harvested by $155 \mathrm{hp}$ $(114 \mathrm{~kW})$ tractor with a working width of $3.4 \mathrm{~m}$ mower running at an average $12 \mathrm{~km} \mathrm{~h}^{-1}$ speed. Grass was raked up by an $8 \mathrm{~m}$ rake, pulled by $105 \mathrm{hp}(77 \mathrm{~kW})$ tractor at an average $10 \mathrm{~km} \mathrm{~h}^{-1}$ speed. The grass was collected and chopped (3-8 mm pieces) by a combine of $456 \mathrm{hp}(335 \mathrm{~kW})$ with a dedicated grass-cutter. Biomass from the field was transported by two $155 \mathrm{hp}(114 \mathrm{~kW})$ tractors with trailers of 14-ton capacity to the place of ensiling and ensiled in trenches later. During cutting, transportation and ensiling grass naturally wilts. At harvesting, transportation and ensiling, biomass losses do not exceed $2 \%$ of the total biomass produced (Bacenetti et al., 2013). Perennial grass biomass was transported into silage trenches and by 155 $\mathrm{hp}(114 \mathrm{~kW})$ tractor smoothed evenly over the area and compressed to the average on-farm ensiling density of $200 \mathrm{~kg} \mathrm{~m}^{-3}$ dry matter (DM) density (Digman et al., 2010). Ensiling process naturally occurs due to the presence of organic acids or the use of chemical preservatives. The silage quality and flavour characteristics were irrelevant because it is used for biogas. Silage was maintained at least 70 days in trenches. Then the heap was opened and silage transported by a $105 \mathrm{hp}(77 \mathrm{~kW})$ tractor with front loader into the stationary biomass mixing and dosing device, which mixed it with the liquid fraction and by a screw conveyor delivered to the anaerobic digester. 
Anaerobic digestion of perennial grasses was carried out in a cylindrical continuous operation biogas digester, made of steel or reinforced concrete structures. The digester was maintained in a mesophilic environment at $38 \pm 1{ }^{\circ} \mathrm{C}$ temperature and volumetric organic loading rate of $2 \mathrm{~kg} \mathrm{~m}^{3} \mathrm{~d}^{-1}$. Additionally, water was used in order to maintain a steady dry matter concentration of $14-17 \%$ in the feedstock. Losses of biogas in the production process are from $0.3 \%$ up to $1.5 \%$ of the total amount of biogas produced (Jury et al., 2010; Dressler et al., 2012; Lijó et al., 2014). Extracted biogas was cleaned of impurities and compressed and supplied to cogeneration unit where burned in an internal combustion engine that drives a generator of $500 \mathrm{~kW}_{\mathrm{e}}(36.1 \%$ electrical efficiency and $46.5 \%$ thermal efficiency). Electricity produced was used for biogas plant processes and redundant power was supplied to the power distribution networks. Thermal energy obtained from the engine cooling and exhaust systems was used to heat the feedstock and maintain the required temperature in the digester. Excess thermal energy was supplied to other consumers. Similar characterisation methodology for biogas plant power determination was applied by Bacenetti et al. (2013). Digested substrate was pumped into digested substrate storage reservoir. From the reservoir, the substrate was transported by $155 \mathrm{hp}(114 \mathrm{~kW})$ tractor with slurry tanker $\left(24 \mathrm{~m}^{3}\right)$ to the fields for fertilization of perennial grasses. The investigation of biogas yield in this paper is based on the results of laboratory experiments conducted in Biogas Laboratory at Aleksandras Stulginskis University. The biogas yield was investigated using laboratory equipment consisting of 201 digesters, operated in continuous mode at $38 \pm 0.5^{\circ} \mathrm{C}$ in order to simulate actual conditions of an agricultural biogas plant. Therefore environmental impact was adapted to the Baltic region.

The environmental impact assessment allows a complex comparison of the processes occurring separately and together according to impact on environment and to determine the biogas production stages which affect the environment the most. The assessment of sustainability indicators starts with raw material extraction stage and ends with consumption of biogas for heat generation or cogeneration plant and the substrate spreading on a field. Environmental impact assessment of the whole process of biogas production from perennial grasses is carried out in accordance with EN ISO 14040 and EN ISO 14044 (2006) standards. The EDIP 2003 and IMPACT 2002+ models were used together with software SimaPro 8 (Humbert et al., 2012). The EDIP 2003 method translates the cumulated inventory data of an examined system "into potential contributions to various impacts within the main groups environment, resources and working environment" (Frischknecht et al., 2007). The EDIP 2003 method and IMPACT 2002+ method propose an implementation of a combined midpoint/damage approach where all life cycle assessment (LCA) results are linked via midpoint categories (e.g., acidification, eutrophication, global warming, ozone layer depletion, etc.) to four damage categories (Human health, Ecosystem quality, Climate change, Resources) (Dressler et al., 2012). Only those larger than 5\% equivalent factors were taken into account. Data on plant biomass preparation, transportation, biogas plant and equipment were taken from database Ecoinvent v3 (2014). Comparative functional unit $1 \mathrm{kWh}_{\mathrm{e}}$ electricity generated by the biogas plant was selected.

The data on gaseous emissions was taken from the database Ecoinvent (2014). To the greenhouse gas (GHG) emissions have been assigned $\mathrm{CO}_{2}, \mathrm{CH}_{4}, \mathrm{~N}_{2} \mathrm{O}$ and other gases such as hydrofluorocarbons (HFCs), sulphur hexafluoride $\left(\mathrm{SF}_{6}\right)$ and indirectly affecting $\mathrm{CO}$, $\mathrm{NO}_{x}, \mathrm{SO}_{2}$ gas, volatile hydrocarbons. The total amount of GHG emissions is presented in $\mathrm{kg} \mathrm{CO}_{2} \mathrm{eq} \mathrm{kg}^{-1}$ material equivalent, whereas the various GHG are measured by their global warming potential (determined for each material) per 100 years (IPCC, 2006; Navickas, Venslauskas, 2012; Heffels et al., 2014). Global warming potentials for the main $\mathrm{GHG}$ (carbon dioxide $\left(\mathrm{CO}_{2}\right)$, methane $\left(\mathrm{CH}_{4}\right)$ and nitrous oxide $\left.\left(\mathrm{N}_{2} \mathrm{O}\right)\right)$ taken into account, were 1, 23 and 296, respectively (EN ISO 14040:2006; EN ISO 14044:2006). GHG emissions occurring at the anaerobic digestion can be identified by measured $\mathrm{CH}_{4}$ and $\mathrm{CO}_{2}$ yields, gas leakage and emissions of energy input.

\section{Results and discussion}

One of the parameters in evaluating biomass suitability as the substrate for biogas is biomass yield. In the first year of sward use, dry matter (DM) yield of tall fescue cut twice per vegetation season was higher compared to that cut three times, while cocksfoot and reed canary grass yielded better cut three times compared to cut twice (Fig. 3). The results of analysis of variance indicated that annual dry matter yield of investigated swards was significantly influenced by the interaction between grass species and number of cuts $\left(\mathrm{F}_{\text {fact. }}=4.35^{* *}, \mathrm{LSD}_{05}=0.395\right)$. The highest yield was obtained in tall fescue swards cut twice and fertilized with $\mathrm{N}_{180}(\mathrm{SC} 8)$. In this treatment, tall fescue accumulated the highest biomass yield till the first cut (about $70 \%$ of annual DM yield). All swards, fertilized with $180 \mathrm{~kg} \mathrm{ha}^{-1} \mathrm{~N}$ exhibited significantly higher biomass yield $\left(\mathrm{F}_{\text {fact. }}=18.42 * *, \mathrm{LSD}_{05}=0.228\right)$ compared to those fertilized with $90 \mathrm{~kg} \mathrm{ha}^{-1} \mathrm{~N}$. The results of analysis of variance also indicated that annual biomass yield of swards was significantly influenced by the interaction of grass species and number of cuts per vegetation season $\left(\mathrm{F}_{\text {fact. }}=4.35^{* *}, \mathrm{LSD}_{05}=0.395\right)$. The highest effect was obtained in tall fescue swards.

The yield of perennial grasses, dry matter content and biogas yield differed significantly. Therefore in order to ensure a steady operation of hypothetical 500 $\mathrm{kW}$ electric power cogeneration power plant, i.e. an even feeding of biogas, biogas digester size and technological equipment needed for anaerobic digestion in calculations were different. The methodology is similar to that of Hartmann (2006) who performed LCA for $1 \mathrm{MW}_{\mathrm{e}}$ installed electric power biogas plant. Results of other researchers (Dressler et al., 2012; Bacenetti et al., 2013) show that $1 \mathrm{~kW}_{\mathrm{e}}$ electricity generated by the biogas plant as a functional unit is acceptable. Other authors use 100 $\mathrm{kWh}$ electricity generated (Lijó et al., 2014) or 1 ton of organic material (feedstock) digested (Poeschl et al., 2012 a) when the aim is to compare the best uses for a given biomass feedstock.

Three grass species were analysed in terms of biogas yields giving energy potential. The results of digestion of perennial grasses are presented in Table. 


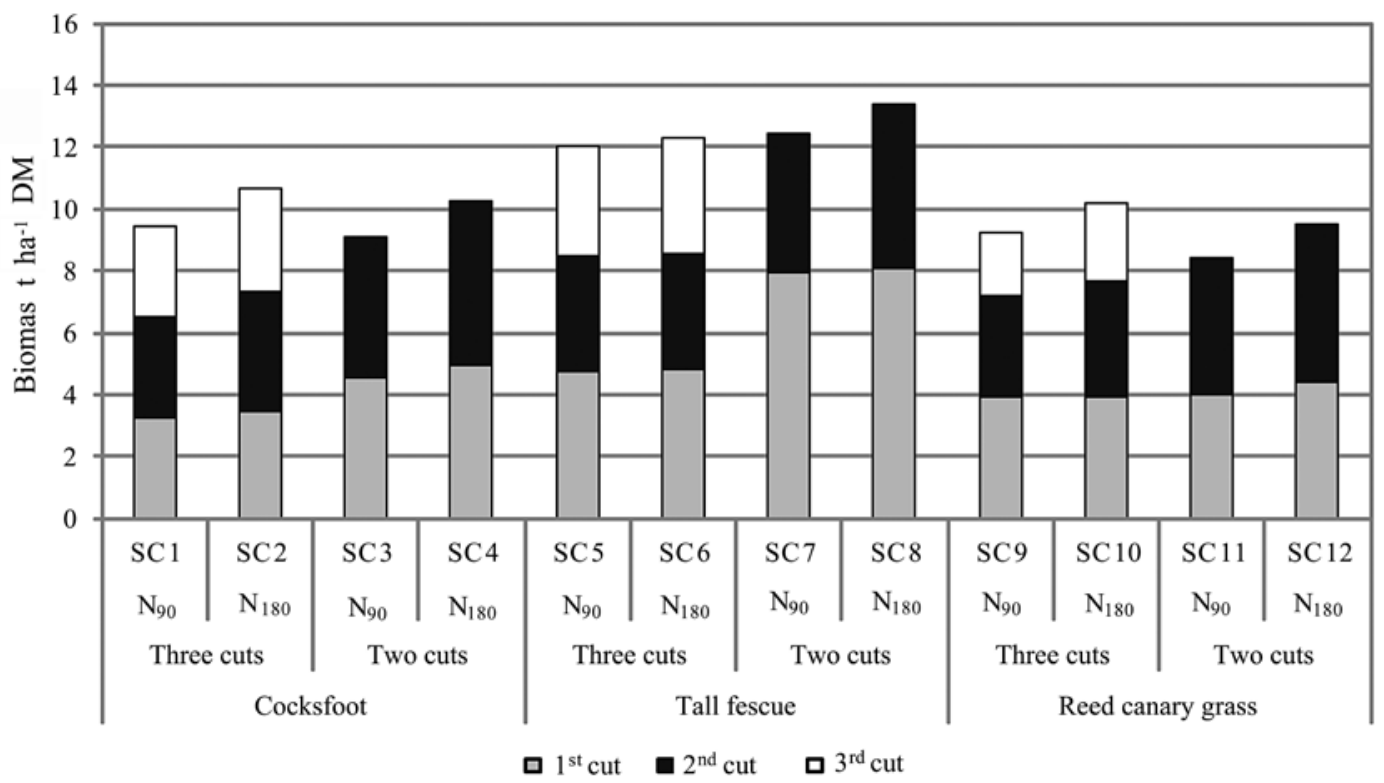

$\mathrm{LSD}_{05}$ - grass species (A) - 0.323, number of cuts $(\mathrm{B})-0.228$, nitrogen fertilization $(\mathrm{C})-0.228$; $\mathrm{A} \times \mathrm{B}-0.395, \mathrm{~A} \times \mathrm{C}-0.395$, B $\times \mathrm{C}-0.395, \mathrm{~A} \times \mathrm{B} \times \mathrm{C}-0.650$

Figure 3. Biomass yield of tall fescue, cocksfoot and reed canary grass in the first year of use, results averaged over two experiments

Table. Indicators of biogas production from perennial grass

\begin{tabular}{|c|c|c|c|c|c|c|c|c|c|c|}
\hline Scenario & $\begin{array}{l}\text { TS } \\
\%\end{array}$ & $\begin{array}{l}\text { VS } \\
\%\end{array}$ & $\begin{array}{c}\mathrm{B}_{\mathrm{TS}} \\
1 \mathrm{~kg}^{-1}\end{array}$ & $\begin{array}{c}\mathrm{B}_{\mathrm{vs}} \\
1 \mathrm{~kg}^{-1}\end{array}$ & $\underset{1 \mathrm{~kg}^{-1}}{\mathrm{~B}_{\mathrm{H}}}$ & $\begin{array}{l}\mathrm{C}_{\mathrm{M}} \\
\%\end{array}$ & $\begin{array}{c}e_{\mathrm{TS}} \\
\mathrm{MJ} \mathrm{kg}^{-1}\end{array}$ & $\begin{array}{c}e_{\mathrm{vs}} \mathrm{MJ} \\
\mathrm{kg}^{-1}\end{array}$ & $\begin{array}{c}e_{\mathrm{M}} \\
\mathrm{MJ} \mathrm{kg}^{-1}\end{array}$ & $\begin{array}{c}\mathrm{CO}_{2} \\
\%\end{array}$ \\
\hline $\mathrm{SC} 1$ & \multirow[b]{2}{*}{32.20} & \multirow[b]{2}{*}{30.37} & 762.89 & 808.86 & 245.65 & 58.8 & 15.8 & 16.8 & 5.1 & 41.2 \\
\hline $\begin{array}{l}\mathrm{SC} 2 \\
\mathrm{SC} 3 \\
\mathrm{SC} 4\end{array}$ & & & 620.81 & 658.22 & 199.90 & 61.3 & 13.4 & 14.2 & 4.3 & 38.7 \\
\hline $\begin{array}{l}\text { SC5 } \\
\text { SC6 }\end{array}$ & \multirow{2}{*}{29.70} & \multirow{2}{*}{27.14} & 728.96 & 797.72 & 216.50 & 59.1 & 15.2 & 16.6 & 4.5 & 40.9 \\
\hline $\begin{array}{l}\text { SC7 } \\
\text { SC8 }\end{array}$ & & & 728.28 & 796.98 & 216.30 & 61.0 & 15.7 & 17.2 & 4.7 & 39.0 \\
\hline $\begin{array}{c}\text { SC9 } \\
\text { SC10 }\end{array}$ & \multirow{2}{*}{28.20} & \multirow{2}{*}{26.46} & 600.00 & 639.46 & 169.20 & 61.0 & 12.9 & 13.8 & 3.6 & 39.0 \\
\hline $\begin{array}{l}\mathrm{SC} 11 \\
\mathrm{SC} 12\end{array}$ & & & 567.91 & 605.25 & 160.15 & 60.7 & 12.2 & 13.0 & 3.4 & 39.3 \\
\hline
\end{tabular}

TS - total solids, VS - volatile solids, $\mathrm{B}_{\mathrm{TS}}$ - cumulative biogas yield from total solids, $\mathrm{B}_{\mathrm{vS}}-$ cumulative biogas yield from volatile solids, $\mathrm{B}_{\mathrm{M}}$ - cumulative biogas yield from biomass, $\mathrm{C}_{\mathrm{M}}$ - concentration of methane in biogas, $e_{\mathrm{TS}}-$ calorific value of total solids, $e_{\mathrm{vs}}-$ calorific value of volatile solids, $e_{\mathrm{M}}-$ calorific value of biomass

Similar results were obtained by Seppälä et al. (2009) who used the same grass species and obtained slightly lower specific methane yield (from 264 to 3101 $\mathrm{CH}_{4} \mathrm{~kg}^{-1}$ total solids (TS), compared to our results -345 to $448 \mathrm{l} \mathrm{CH}_{4} \mathrm{~kg}^{-1} \mathrm{TS}$. Hutňan and colleagues (2010) investigated maize as a feedstock for biogas and obtained $510-5901 \mathrm{~kg}^{-1}$ volatile solids (VS) at organic load of $2.1 \mathrm{~kg} \mathrm{~m}^{-3} \mathrm{~d}^{-1}$. These results are promising for grass silage application for biogas as biomass resource similar to maize. In order to ensure a steady operation of $500 \mathrm{~kW}_{\mathrm{e}}$ installed power biogas plant, the 8000 full load hours per year was used in a model. Hartmann (2006) suggests using 7800 full load hours per year. It is believed that the successfully operating biogas plant must operate not less than 8500 hours (Horbelt et al., 2011). The different field area has to be tillaged depends on the yield of perennial grass biomass and biogas production (Fig. 4).

The largest area is needed for the same amount of energy to extract is in SC11, when reed canary grass is cultivated, cut twice per season and fertilized with $90 \mathrm{~kg} \mathrm{ha}^{-1}$ of nitrogen. The minimum area is required for SC8, when tall fescue is cultivated; cut twice per season and $180 \mathrm{~kg} \mathrm{ha}^{-1}$ of nitrogen is applied. Theoretically grass should be cut up to five times per year for the production of silage for biogas (Hartmann, 2006). Depending on climatic conditions in Northern European regions three or two cuts were chosen per vegetative season. The feedstock intended for biogas plants should have as low as possible lignification rate. The available literature shows that grass from late cut should not be used in biogas plants, 


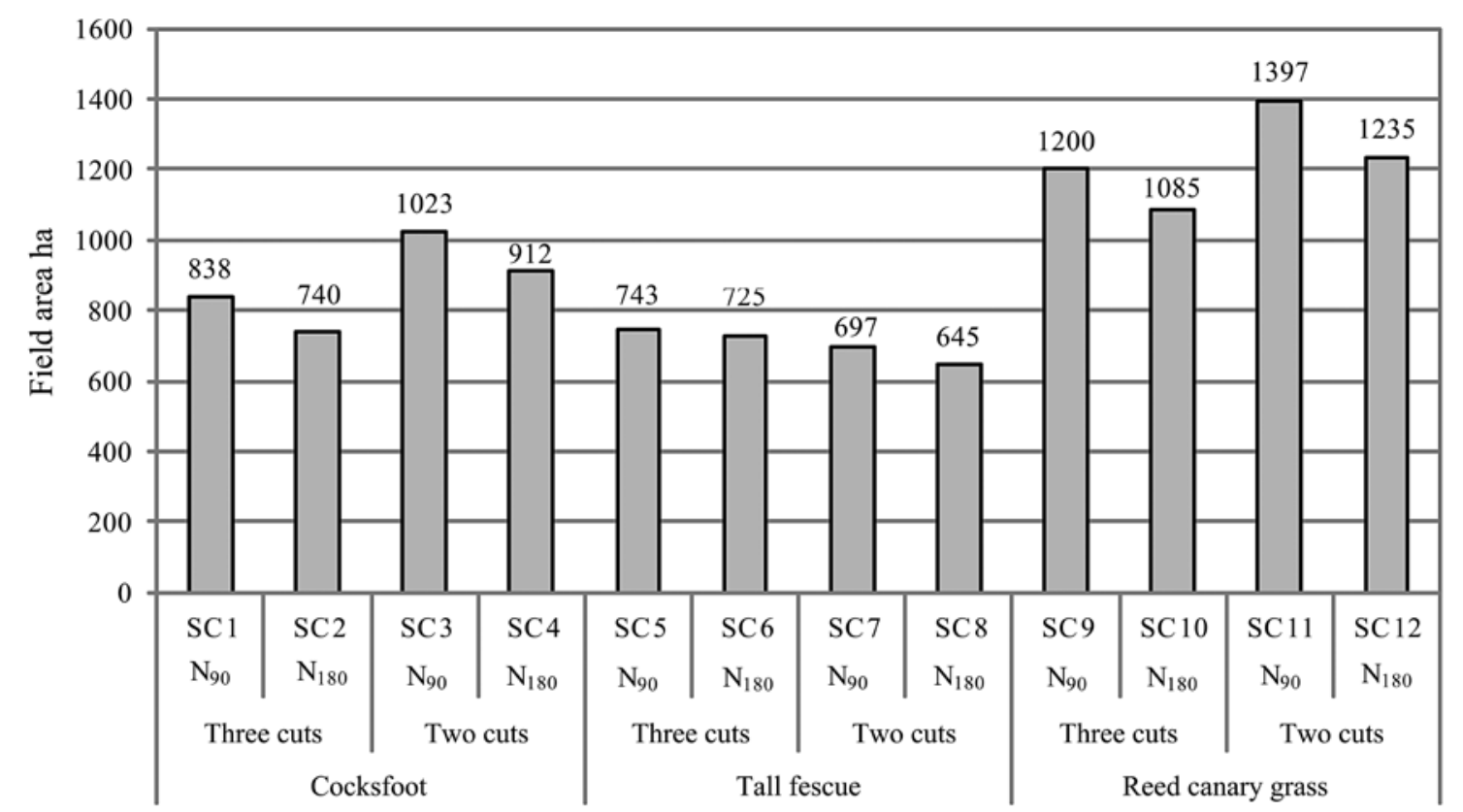

Figure 4. Field area required for biomass production in order to ensure stable energy generation in the biogas plant

due to its high content of lignin and cellulose (Hartmann, 2006; Seppälä et al., 2009). The $\mathrm{CH}_{4}$ concentrations in the extracted biogas ranged from $59 \%$ to $62 \%$. This concentration is in the range of average methane content in biogas produced from plant biomass, which ranges from $48 \%$ to $71 \%$ in biogas produces from mixture of grasses (Demirel et al., 2010). Electricity produced at biogas plant is used for technological processes which need from 20 to $23 \mathrm{kWh}$ depending on species of grass. Meanwhile, the surplus energy is supplied to the electricity distribution networks. Thermal energy taken from the engine cooling and exhaust system (from 189 up to $236 \mathrm{MJ} \mathrm{h}^{-1}$ ) is used to heat the feedstock, and from 7.8 up to $8.3 \mathrm{MJ} \mathrm{h}^{-1}$ to maintain the required temperature in the digesters.

The present results show that tall fescue is the most suitable grass for biogas production in terms of field area requirements, i.e. it needs less land compared to cocksfoot and reed canary grass. To maintain $500 \mathrm{~kW}_{\mathrm{e}}$ biogas plant the tall fescue area differs from 645 to 743 ha depending on fertilization and number of cuts, while the cocksfoot requires from 740 to 1023 ha and reed canary grass - 1085-1397 ha.

The total balance of GHG emissions of all scenarios positively influences environment and ranges from -0.206 to $-0.298 \mathrm{~kg} \mathrm{CO}_{2}$ eq $\mathrm{kWh}^{-1}$ (Fig. 5). It was found that the lowest mitigation of GHG emissions has scenario SC11 $\left(-0.206 \mathrm{~kg} \mathrm{CO}_{2}\right.$ eq kWh$\left.^{-1}\right)$ when reed canary grass, cut twice per season at flowering stage, fertilized with $90 \mathrm{~kg} \mathrm{ha}^{-1}$ of nitrogen. It was mostly influenced by a relatively low reed canary grass yield of $8.4 \mathrm{tha}^{-1}$ and a low biogas yield $\left(169.21 \mathrm{~kg}^{-1}\right)$. However, the scenario reed canary grass cut three times during the season (SC10); fertilized with $180 \mathrm{~kg} \mathrm{ha}^{-1}$ of nitrogen has quite a significant $-0.244 \mathrm{~kg} \mathrm{CO}_{2} \mathrm{eq} \mathrm{kWh}^{-1}$ positive impact on the environment. This resulted from a high yield of $9.5 \mathrm{tha}^{-1}$ and significantly less land area (1085 ha) of grassland. Bacenetti et al. (2013) reported GHG emissions in range
$-0.230-0.286 \mathrm{~kg} \mathrm{CO}_{2}$ eq $\mathrm{kWh}_{\mathrm{e}}^{-1}$ for the two biogas plants (520 and $999 \mathrm{~kW}_{\mathrm{e}}$ installed electrical power), fed mainly with maize silage for Italian region. The emission of $-0.142 \mathrm{~kg} \mathrm{CO}_{2}$ eq $\mathrm{kWh}^{-1}$ was mitigated in maize and triticale silage digestion reported by (Lijó et al., 2014).

The highest positive impact on the global climate warming has scenario SC8 $(-0.298 \mathrm{~kg} \mathrm{CO}$ eq $\mathrm{kWh}^{-1}$ ) when tall fescue was cut three times during the season and fertilized with $180 \mathrm{~kg} \mathrm{ha}^{-1}$ of nitrogen. The positive influence is caused by the fact that SC 8 requires the smallest grassland area (645 ha) and biogas yield is one of the largest and reaches $7281 \mathrm{~kg}^{-1}$ of dry mass. The least positive impact on the environment $(-0.290 \mathrm{~kg}$ $\mathrm{CO}_{2}$ eq $\mathrm{kWh}^{-1}$ ) was found for tall fescue (SC5) where it was cut three times during the season and fertilized with $90 \mathrm{~kg} \mathrm{ha}^{-1}$ of nitrogen. This was influenced by the greater area of grassland 743 ha and methane (59\%) content in biogas. The highest positive impact on the global climate warming has SC2 $--0.291 \mathrm{~kg} \mathrm{CO}_{2}$ eq $\mathrm{kWh}^{-1}$, when the cocksfoot grass was cultivated on 740 ha of land and cut three times during the season, fertilized with $180 \mathrm{~kg} \mathrm{ha}^{-1}$ of nitrogen. The least positive impact on the global climate warming has scenario SC3 $-0.252 \mathrm{~kg} \mathrm{CO}_{2}$ eq kWh$^{-1}$.

Biogas plants have a uniquely positive $\mathrm{CO}_{2}$ balance. Results of Poeschl et al. (2012 a) show the $-55.3 \mathrm{~kg} \mathrm{CO}_{2}$ eq $\mathrm{t}^{-1}$ feedstock in the case of grass silage digestion. The losses of methane during biomass processing, digestion and post-processing could have higher GHG impact if considering lower $(0.3 \%)$ or higher - up to $4 \%$ from produced biogas. This has to be taken into consideration for sensitivity analyses. According to calculations by Fachverband Biogas e.V. (Horbelt et al., 2011), one kWh of electricity causes $290 \mathrm{~g}$ of $\mathrm{CO}_{2}$ eq. By comparison, generating the same amount of electricity from a fossil energy mix releases $720 \mathrm{~g}$ of $\mathrm{CO}_{2}$ eq. Consequently, the biogas plant saves $430 \mathrm{~g}$ of $\mathrm{CO}_{2}$ eq or $60 \%$ of the climate gas for every $\mathrm{kWh}$ generated. 


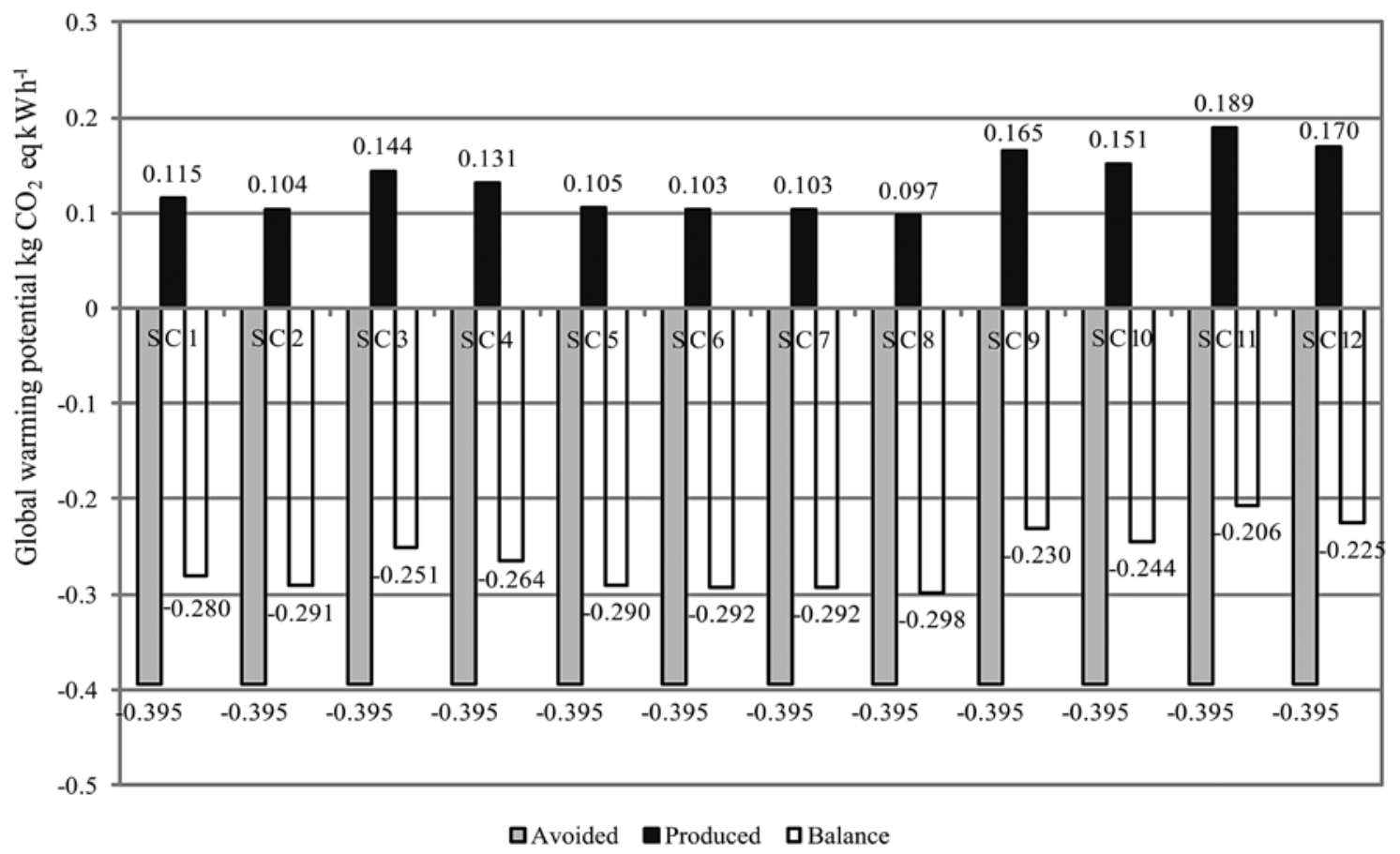

Figure 5. Potential of greenhouse gas (GHG) emissions

\section{Conclusions}

1. Annual biomass yield of swards was significantly influenced by the interaction of grass species and number of cuts per vegetation season.

2. Tall fescue (Festuca arundinacea Scherb.) is the most suitable grass for biogas production in terms of field area requirements. To assure the energy generation of $500 \mathrm{~kW}_{\mathrm{e}}$ biogas plant the tall fescue should be cultivated in the area from 645 to 743 ha depending on fertilization rate and number of cuts.

3. The mitigation of greenhouse gas (GHG) emissions for energy production from perennial grasses varies in the range $0.206-0.298 \mathrm{~kg} \mathrm{CO}_{2}$ eq $\mathrm{kWh}^{-1}$ depending on the species and technology of cultivation. The highest positive GHG mitigation effect was found for tall fescue grass, cut three times during the season, fertilized with $180 \mathrm{~kg} \mathrm{ha}^{-1}$ of nitrogen.

Received 30042014

Accepted 26062014

\section{References}

Bacenetti J., Negri M., Fiala M., González-García S. 2013. Anaerobic digestion of different feedstocks: impact on energetic and environmental balances of biogas process. Science of the Total Environment. 463-464: 541-551 http://dx.doi.org/10.1016/j.scitotenv.2013.06.058

Butkutè B., Lemežienė N., Kanapeckas J., Navickas K. Dabkevičius Z., Venslauskas K. 2014. Cocksfoot, tall fescue and reed canary grass: dry matter yield, chemical composition and biomass convertibility to methane. Biomass and Bioenergy, 66: 1-11 http://dx.doi.org/10.1016/j.biombioe.2014.03.0145

Cornejo C., Wilkie A. C. 2010. Greenhouse gas emissions and biogas potential from livestock in Ecuador. Energy for Sustainable Development. 14: 256-266 http://dx.doi.org/10.1016/j.esd.2010.09.008

Demirel B., Scherer P., Yenigun O., Onay T. T. 2010 Production of methane and hydrogen from biomass through conventional and high-rate anaerobic digestion processes. Critical Reviews in Environmental Science and Technologv. 40: 116-146 http://dx.doi.org/10.1080/10643380802013415

Digman M. F., Shinners K. J., Casler M. D., Dien B. S., Hatfield R. D., Jung H. J. G., Muck R. E., Weimer P. J. 2010. Optimizing on-farm pretreatment of perennial grasses for fuel ethanol production. Bioresource Technology, 101 (14): 5305-5314 http://dx.doi.org/10.1016/j.biortech.2010.02.014

Dressler D., Loewen A., Nelles M. 2012. Life cycle assessment of the supply and use of bioenergy: impact of regional factors on biogas production. The International Journal of Life Cycle Assessment. 17 (9): 1104-1115 http://dx.doi.org/10.1007/s11367-012-0424-9

Ecoinvent. 2014. Database v3. Swiss Centre for Life Cycle Inventories. $<$ http://www.ecoinvent.org/> [accessed 0804 2014]

EN ISO 14040:2006. Environmental management - Life cycle assessment - Principles and framework

EN ISO 14044:2006. Environmental management - Life cycle assessment - Requirements and quidelines

Frischknecht R., Jungbluth N., Althaus H. J., Bauer C., Doka G., Dones R., Hischier R., Hellweg S., Humbert S., Köllner T., Loerincik Y., Margni M., Nemecek T. 2007. Implementation of life cycle impact assessment methods. Ecoinvent report No. 3. Swiss Centre for Life Cycle Inventories. <http://www.pre-sustainability.com/ download/manuals/ EcoinventImpactAssessmentMethods. pdf $>$ [accessed 0702 2014]

Grieder C., Mittweg G., Dhillon B. S., Montes J. M., Orsini E., Melchinger A. E. 2012. Kinetics of methane fermentation yield in biogas reactors: genetic variation and association with chemical composition in maize. Biomass and Bioenergv. 37: 132-141 http://dx.doi.org/10.1016/j.biombioe.2011.12.020

Hartmann J. K. 2006. Life cycle assessment of industrial scale biogas plants: dissertation. University of Göttingen, Sweden

Heffels T., McKenna R., Fichtner W. 2014. An ecological and economic assessment of absorption-enhanced-reforming (AER) biomass gasification. Energy Conversion and Management. 77: 535-544 http://dx.doi.org/10.1016/j.enconman.2013.09.007 
Horbelt A., Maciejczyk M., Olzem B., Rauh S. 2011. Biogas can do it: facts, arguments and potentials. Fachverband Biogas e.V., 40 p.

Humbert S., De Schryver A., Bengoa X., Margni M., Jolliet O. 2012. IMPACT 2002+: user guide, version Q2.21. Quantis, $40 \mathrm{p}$.

Hutňan M., Špalková V., Bodík I., Kolesárová N., Lazor M. 2010. Biogas production from maize grains and maize silage. Polish Journal of Environmental Studies, 19 (2): 323-329

IPCC 2006. 2006 IPCC Guidelines for National Greenhouse Gas Inventories. Prepared by the National Greenhouse Gas Inventories Programme of the intergovernmental panel on climate change. Institute for Global Environmental Strategies. $<\mathrm{http}: / /$ www.ipcc-nggip.iges.or.jp/public/2006gl/ index.html $>$ [accessed 1303 2014]

Jury C., Benetto E., Koster D., Schmitt B., Welfring J. 2010. Life cycle assessment of biogas production by monofermentation of energy crops and injection into the natural gas grid. Biomass and Bioenergv. 34: 54-66 http://dx.doi.org/10.1016/j.biombioe.2009.09.011

Klinglmair M., Sala S., Brandão M. 2014. Assessing resource depletion in LCA: a review of methods and methodological issues. The International Journal of Life Cycle Assessment, 19: $580-592$

http://dx.doi.org/10.1007/s11367-013-0650-9

Lijó L., González-García S., Bacenetti J., Fiala M., Feijoo G., Lema J. M., Moreira M. T. 2014. Life cycle assessment of electricity production in Italy from anaerobic co-digestion of pig slurry and energy crops. Renewable Energy. 68: 625-635 http://dx.doi.org/10.1016/j.renene.2014.03.005

Navickas K., Venslauskas K. 2012. Life cycle assessment of biomass. Aleksandras Stulginskis University, 82 p. (in Lithuanian)

Navickas K., Venslauskas K., Župerka V. 2008. Mitigation of global warming gases using anaerobic digestion of biomass. Žemès ūkio inžinerija, 40 (2): 27-38 (in Lithuanian)
Poeschl M., Ward S., Owende P. 2010. Integrated assessment of biogas technology options. Biosystems Engineering Research Review, 15: 155-158

Poeschl M., Ward S., Owende P. 2012 (a). Environmental impacts of biogas deployment. Part I. Life cycle inventory for evaluation of production process emissions to air. Journal of Cleaner Production. 24: 168-183 http://dx.doi.org/10.1016/j.jclepro.2011.10.039

Poeschl M., Ward S., Owende P. 2012 (b). Environmental impacts of biogas deployment. Part II. Life cycle assessment of multiple production and utilization pathways. Journal of Cleaner Production. 24: 184-201 http://dx.doi.org/10.1016/j.jclepro.2011.10.030

Seppälä M., Paavola T., Lehtomaki A., Rintala J. 2009. Biogas production from boreal herbaceous grasses - specific methane yield and methane yield per hectare. Bioresource Technologv. 100 (12): 2952-2958 http://dx.doi.org/10.1016/j.biortech.2009.01.044

Seppälä M., Pyykkönen V., Laine A., Rintala J. 2012. Methane production from maize in Finland - screening for different maize varieties and plant parts. Biomass and Bioenergy, 46: $282-290$ http://dx.doi.org/10.1016/j.biombioe.2012.08.016

Tilvikienė V., Venslauskas K., Navickas K., Z̈uperka V., Dabkevičius Z., Kadžiulienė Ž. 2012. The biomass and biogas productivity of perennial grasses. ZemdirbysteAgriculture, 99 (1): 17-22

Wilkie A. C. 2008. Opportunities for reducing greenhouse gas emissions through livestock waste management in Florida. MulkeyS.etal.(eds).Opportunitiesforgreenhousegasreduction through forestry and agriculture in Florida. $<$ http://biogas. ifas.ufl.edu/Publs/ReducingFloridaGHG-p33-38-2008.pdf> [accessed 1303 2014]

\title{
ISSN 1392-3196 / e-ISSN 2335-8947
}

Zemdirbyste-Agriculture, vol. 101, No. 3 (2014), p. 271-278

DOI $10.13080 / \mathrm{z}-\mathrm{a} .2014 .101 .035$

\section{Daugiamečių žolių energinès biomasès, naudojamos biodujų gamybai, potencialo ir šiltnamio efektą sukeliančių dujų emisijų vertinimas}

\author{
A. Nekrošius ${ }^{1}$, K. Navickas ${ }^{1}$, K. Venslauskas ${ }^{1}$, Ž. Kadžiuliené ${ }^{2}$, V. Tilvikiené2 \\ ${ }^{1}$ Aleksandro Stulginskio universitetas \\ ${ }^{2}$ Lietuvos agrarinių ir miškų mokslų centro Žemdirbystès institutas
}

\section{Santrauka}

Tyrimų metu įvertintos energinės biomasės ir biodujų gamybos iš ịvairių daugiamečių žolių siloso šiltnamio efektą sukeliančių dujų emisijos, apimant visus procesus nuo biomasès auginimo iki perdirbimo ị biodujas.

Tyrimams pasirinktos daugiametès miglinių rūšies žolès - paprastoji šunažolè (Dactylis glomerata L.), nendrinis eraičinas (Festuca arundinacea Scherb.) ir nendrinis dryžutis (Phalaris arundinacea L.), užaugintos Lietuvos agrarinių ir miškų mokslo centro Žemdirbystès institute 2008-2010 m. Žolynai buvo auginti giliau karbonatingame giliau glèjiškame rudžemyje (RDg4-k2), kuriame organinès anglies buvo 1,61-1,75 \%, judriujų P - 145-224 ir $\mathrm{K}-128-158 \mathrm{mg} \mathrm{kg}^{-1}$, dirvos $\mathrm{pH}-6,7-7,0$. Siekiant užtikrinti stabilų $500 \mathrm{~kW}_{\mathrm{e}}$ elektrinès galios biodujų jègainès darbą, buvo naudota trijų daugiamečių žolių biomasè. Šios biodujų jègainès nepertraukiamam darbui reikalingoms žaliavoms užtikrinti būtini ịvairaus dydžio žemès plotai, priklausomai nuo žolynų derlingumo.

Daugiamečiu žolių plotai, kurių reikia pagaminti tam pačiam kiekiui energijos, priklauso nuo žolių rūšies, trę̌simo normų ir pjūčių kiekio. Tyrimų rezultatai labiausiai priklausè nuo biomasès derlingumo ir biodujų išeigos iš sausosios masès. Nendrinio eraičino biomasès sausosios masės derlingumas, pirmaisiais naudojimo metais pjauto du kartus per vegetacijos sezoną, buvo didesnis už pjauto tris kartus, o paprastosios šunažolès ir nendrinio dryžučio derlingumas buvo didesnis pjaunant tris kartus. Suminis šiltnamio efektą sukeliančių dujų balansas rode šių dujų emisijų sumažejimą ir kito nuo 0,206 iki $0,298 \mathrm{~kg} \mathrm{CO}_{2} \mathrm{ekv} . \mathrm{kWh}^{-1}$.

Reikšminiai žodžiai: anaerobinis perdirbimas, būvio ciklo vertinimas, energiniai augalai. 